\title{
Jeremias Hentschel Lesna Polonus (1662-1709) i jego księgozbiór. Fragment z dziejów biblioteki parafii luterańskiej w Lesznie
}

Streszczenie. Artykuł przedstawia postać diakona parafii luterańskiej w Lesznie Jeremiasa Hentschela (1662-1709), jego piśmienniczą aktywność oraz zbiór książek, które przekazał ufundowanej przez siebie bibliotece parafialnej. Przedmiotem daru była kwota 940 guldenów na budowę pomieszczenia biblioteki oraz 144 dzieła w 25 tomach, które nabył w latach 1682-1687. Woluminy te mają charakterystyczną proweniencję: wytłoczony na pergaminowych okładkach akronim JHLP - Jeremias Hentschel Lesna Polonus.

Omawiany zbiór obejmuje liczne dysertacje akademickie wydane w czołowych ośrodkach ortodoksji luterańskiej, głównie w Jenie i Wittenberdze, teksty z zakresu filozofii, historii Kościoła, polemiki z innymi wyznaniami chrześcijańskimi. Teksty niereligijne stanowią margines.

SŁowA KLUCzowe: księgozbiory, protestantyzm, Leszno, proweniencje, XVIIXVIII wiek.

Na zbiory wielkich bibliotek składają się nierzadko pojedyncze dary osób związanych z instytucjami będącymi właścicielami owych księgozbiorów. W przypadku biblioteki parafialnej mamy zazwyczaj do czynienia z dziełami ofiarowanymi przez duchownych i wiernych należących do danej wspólnoty. Jeśli dysponujemy dokumentacja, w której odnotowano fakt donacji, lub gdy na egzemplarzach dzieł znajdują się znaki proweniencyjne naniesione przez kolejnych właścicieli, możliwe jest odtworzenie losów konkretnych książek i zidentyfikowanie ofiarodawców. Księgozbiór taki przestaje być jedynie zbiorem tomów i zyskuje nową wartość - własną historię.

Biblioteka dawnej parafii ewangelicko-augsburskiej Kreuzkirche w Lesznie, której fragmentem jest zbiór będący przedmiotem niniejszego 
opracowania - w przeciwieństwie do wielu innych historycznych księgozbiorów - miała mimo wszystko sporo szczęścia, ponieważ jakkolwiek uszczuplona, dotrwała do czasów nam współczesnych ${ }^{1}$. Według zapisów inwentarza biblioteki z 1848 roku stan księgozbioru zamykał się tego roku w liczbie 1355 dzieł w 2015 tomach. Obecnie 352 jednostki inwentarzowe zachowanych starych druków znajdują się w zbiorach Biblioteki Kórnickiej PAN, dokąd trafiły po II wojnie światowej², zaś w Bibliotece Naukowej Muzeum Okręgowego w Lesznie schronienie znalazły 32 tomy druków wydanych do 1800 roku, przeważnie drobnych rozpraw akademickich tworzących klocki introligatorskie - łącznie 322 druki ${ }^{3}$. Oprócz nich w bibliotece leszczyńskiego muzeum znajduje się pięć druków XIX-wiecznych. Los pozostałych dzieł jest nieznany; zapewne znaczną ich część zniszczono w 1945 roku, kiedy to w opuszczonym kościele stacjonowali radzieccy żołnierze.

Na przestrzeni dziejów biblioteki parafii luterańskiej w Lesznie gromadzeniu książek towarzyszyła troska o ich stan zachowania i umożliwienie orientacji w zasobie. Większość dzieł zgromadzonych w świętokrzyskiej bibliotece oprawiono $\mathrm{w}$ pergamin lub skórę, zaś na grzbietach pergaminowych opraw, w które ujęto liczne drobne broszury - dla ułatwienia poruszania się $\mathrm{w}$ zbiorze - zamieszczono informacje identyfikujące poszczególne tomy, zawierające nazwisko autora, fragment tytułu lub notatkę, np.: „Tomus XIII Miscellaneorum”. Tylko nieliczne książki zdradzają swe wcześniejsze losy znakami własnościowymi: głównie odręcznymi podpisami. W XIX stuleciu wszystkie książki opieczętowano na kartach tytułowych tłokiem o treści: „Sieg d. Evangel. Kreuzkirche zu Lissa. Reg: Bezirk Posen". Zapewne w początkach XX wieku na grzbiety naklejono karteczki z wydrukowanymi kolejnymi numerami, odpowiadającymi zapisom w rękopiśmiennym katalogu. Fakt istnienia starszych, nieznanych dziś, spisów zdradzają znaki liczbowe - najprawdopodobniej kolejne numery inwentarza, zapisane na grzbietach tą samą ręką co dane identyfikujące klocki introligatorskie. Zachowany egzemplarz katalogu kościelnej biblioteki pochodzi z 1848 roku i ujmuje nabytki gromadzone

${ }^{1}$ K. Szymańska, Losy księgozbiorów historycznych parafii ewangelickich w Lesznie, w: Dziedzictwo utracone - dziedzictwo odzyskane, red. A. Kamler, D. Pietrzkiewicz, Warszawa 2014, s. 201-221.

${ }^{2} \mathrm{Na}$ stronie internetowej Biblioteki Kórnickiej PAN dostępny jest katalog online. Wykaz druków z biblioteki kościoła parafii luterańskiej w Lesznie: http://baza1-bis.man.poznan.pl/cgi-bin/makwww.exe?BM=03\&IM=17\&TX=\&NU=05\&WI= KOsCIolbKROBIA [dostęp: 4.06.2015].

${ }^{3}$ K. Szymańska, Katalog starych druków Muzeum Okręgowego w Lesznie, Leszno 2001, s. 254 (Indeks proweniencji). 
od początku istnienia księgozbioru w Lesznie. Niestety nie znajdziemy w tym wykazie żadnych informacji o darczyńcach. Takie dane zamieszczono skrupulatnie w katalogu innej wielkiej biblioteki Leszna, należącej do parafii reformowanej św. Jana ${ }^{4}$. Nie dysponując takim dokumentem, jesteśmy skazani wyłącznie na badanie znaków proweniencyjnych.

W ramach opisywanego zbioru istnieje grupa 144 dzieł w 25 wolumenach, oznaczonych na licach przednich okładek znakiem własnościowym w postaci odciśniętych tłoków z inicjałami "JHLP"; na dziesięciu dodatkowo wytłoczone zostały daty roczne: 1683, 1685, 1686 (il. 2). W posiadaniu przytłaczającej większości druków z tą proweniencją jest Biblioteka Kórnicka PAN (135 dzieł w 22 wolumenach) ${ }^{5}$, natomiast zaledwie dziewięć dzieł w trzech tomach znajduje się w bibliotece Muzeum Okręgowego w Lesznie 6 .

Nieliczne egzemplarze zawierają dodatkowe, wyróżniające je, cechy. $\mathrm{Na}$ jedenastu książkach, na wyklejce pierwszej okładki w prawym dolnym rogu, odnotowane zostały kwoty wydane na ich zakup oraz miejsce dokonania transakcji: Jena lub Lipsk. W jednym przypadku notatka taka znalazła się na karcie tytułowej ${ }^{7}$ (il. 3). Na wyklejkach dwu opasłych klocków introligatorskich starannym charakterem pisma wyszczególniono wszystkie zszyte razem teksty. Czy dokonał tego autor zbioru, czy później opiekujący się biblioteką duchowny, nie sposób jednoznacznie stwierdzić. Należy zauważyć, że również inne tomy z zasobu tej biblioteki - zwłaszcza niektóre klocki introligatorskie - mogły należeć do tego samego właściciela. Może to sugerować - oprócz identycznej oprawy i podobnego charakteru pisma zapisków na wyklejkach, które znajdujemy również na egzemplarzach pozbawionych interesującej nas proweniencji dobór współoprawnych tekstów, które ze względu na czas, miejsce wydania i treść wykazują bardzo bliskie podobieństwo z tomami będącymi

${ }^{4}$ Por. Archiwum Państwowe w Poznaniu [dalej: APP], Akta Braci Czeskich, sygn. 1731.

5 Są to druki o sygnaturach: 2546, 2574, 2576, 2592, 2594, 12381, 12382, 126370-126378, 126397-126400, 126486, 126489, 126539, 126566, 126619, 236004-236098. Część prac to dzieła wielotomowe, zbiory dysput akademickich oprawionych w obszerne klocki introligatorskie, stąd liczba sygnatur nie odpowiada liczbie rekordów w bazie i liczbie wolumenów. Zob.: http://baza1-bis.man.poznan.pl/cgi-bin/makwww.exe?BM=03\&IM=17\&TX=J+H+L+P\&OT=szukaj\&WI=A [dostęp: 4.06.2015].

${ }^{6}$ Są to druki o sygnaturach: S.61-1, S.61-2, S.61-3, S.61-4, S.61-5, S.62-1, S.62-2, S.62-3, S.82.

${ }^{7}$ Informacje o cenie i miejscu nabycia odnotowano na kartach druków Biblioteki Kórnickiej PAN o sygnaturach: 2576, 2592, 126397, 126566, 236004, 236057 oraz na klocku o sygn. S.61 i S.82 ze zbiorów Muzeum Okręgowego w Lesznie. 
przedmiotem niniejszego opracowania ${ }^{8}$. Omówione zostaną jednakże tylko te książki, które mają jednoznacznie określoną proweniencję, a mianowicie superekslibris na przedniej okładce opraw w postaci akronimu „JHLP”, który należy odczytać: Jeremias Hentschel Lesna Polonus9. Ustalenie dysponenta dzieł opatrzonych tą proweniencją nie nastręczyło trudności, ponieważ historia darczyńcy splata się z dziejami biblioteki luterańskiego zboru w Lesznie.

Parafię ewangelicko-augsburską w Lesznie utworzyli w 1628 roku śląscy uchodźcy doby wojny trzydziestoletniej, pochodzący z pobliskiej Góry (Guhrau), oddalonej od Leszna w kierunku południowym o zaledwie około 20 kilometrów. Luteranie osiedli w Lesznie jako zorganizowana wspólnota, w której edukacja i książka odgrywały istotną rolę posiadali własne szkoły: elementarna, tzw. miejską i oddzielną szkołę dla dziewcząt. Przejawiali znaczną aktywność w zakresie działalności piśmienniczej i wydawniczej ${ }^{10}$. Nawet jeśli górzanie nie zdołali przywieźć do Leszna kościelnej biblioteki z dotychczasowego miejsca zamieszkania, to na pewno towarzyszyły im $\mathrm{w}$ przeprowadzce księgi liturgiczne i inne dzieła niezbędne do posługi, które stały się zaczątkiem nowego księgozbioru. Niestety pierwsza wzmianka o nim pochodzi dopiero z początku XVIII wieku i wiąże się z odbudową kościoła po pożarze w 1707 roku $^{11}$. W rzeczywistości budowano wówczas nowy gmach z cegieł, w miejscu dotychczasowego szachulcowego kościoła strawionego przez ogień. Roboty rozpoczęto $\mathrm{w} 1711$ roku. W planie przewidziano miejsce dla biblioteki. Nie wiadomo, czy decyzja ta podyktowana była naturalną potrzebą posiadania takiego lokalu, czy też była konsekwencją zapisu testamentowego uczynionego przez diakona tego kościoła, Jeremiasa Hentschela.

${ }^{8}$ Na wyklejce okładki klocka S.33 ze zbiorów Muzeum Okręgowego w Lesznie zapisano miejsce zakupu i cenę (Leszno, 2 floreny 15 guldenów). Tom zawiera rozprawy akademickie z lat 1650-1690, głównie z lat 80., wydane w Jenie i Wittenberdze. W dwu klockach znajdują się także rozprawy autorstwa darczyńcy z czasu jego studiów w Jenie: S.33-26, S.33-28 i S.50-2.

9 Ten toponim spotykamy na kartach tytułowych dysput akademickich autorstwa Jeremiasa Hentschela z czasu jego studiów w Lipsku i Jenie.

${ }^{10}$ K. Szymańska, Dom ze stów... Wspólnota luterańska w Lesznie w XVII i XVIII wieku w świetle własnej spuścizny literackiej (rekonesans), w: Rzeczpospolita domów, t. 3: Domy Boże, red. K. Krawiec-Złotkowska, Słupsk 2012, s. 551-562.

${ }^{11}$ J. Kohte, Die Kreuz-Kirche in Lissa, ein Denkmal des protestantischen Kirchenbaues, „Mitteilungen”, Historische Gesellschaft für Posen, z. 3, Berlin 1935, s. 24; eadem, Geschichte der protestantischen Kirchenbaues in der Provinz Posen, "Zeitschrift der Historischen Gesellschaft für die Provinz Posen" 1897, t. 12, s. 15. Dzieje budowli i odbudów po kolejnych pożarach podaje: G. Smend, Die Kreuzkirche in Lissa. Ein Beitrag zu ihrer Baugeschichte, Lissa 1910. 
Na krótko przed śmiercią, 23 września 1709 roku, diakon ustanowił testament, na mocy którego ofiarował swój księgozbiór kościelnej bibliotece oraz przekazał na jej budowę 970 guldenów (równowartość 1940 guldenów polskich). Bibliotekę o powierzchni około $30 \mathrm{~m}^{2} \mathrm{z}$ oknem wychodzącym na południe poprzedzała wielka, przestronna sala, w której zapewne odbywały się zborowe spotkania i gdzie można było poświęcić się lekturze. Wejście do biblioteki zabezpieczono podwójnymi drzwiami, nad nimi wmurowano okazałą tablicę z zielonego marmuru w obramowaniu z piaskowca, na której wyryto tekst o treści: „Biblioteca publica B. Jeremiae Hentscheli diaconi hujus ecclesiae literalitate fundata omnibus literatum fautorbus ad usum et augmentum ab anno M.DCC.IX consecrata" (il. 1). Dla upamiętnienia szlachetnego gestu duchownego w 1713 roku mistrz kowalski Deckert wykuł ozdobną kratę ${ }^{12}$, którą wstawiono w okno biblioteki, i zamieścił w niej inicjały donatora „J[eremias] H[entschel D[iakon]" oraz datę roczną 1713. Dodatkowo okno zabezpieczono metalową okiennicą.

Hojny gest duchownego, stojącego w obliczu śmierci, nie dotyczył jedynie biblioteki. Testamentowym zapisem Hentschel ufundował także szpital, który nazywany imieniem darczyńcy, funkcjonował samodzielnie do 1880 roku, a następnie został połączony ze szpitalem św. Jerzego, ufundowanym w 1688 roku przez zamożnego leszczyńskiego kupca i członka rady parafialnej, Georga Stolza ${ }^{13}$.

W XVII wieku było w Lesznie kilka rodzin noszących nazwisko Hentschel, pochodzących z Góry. Zapewne były one ze sobą spokrewnione. Wśród osadników byli na przykład: zmarły w 1643 roku sukiennik Johann i jego żona Dorothea ${ }^{14}$ oraz zamożny kupiec Georg z żoną Dorotheą z Henningów. Ich syn, urodzony już w Lesznie Samuel (1639-1690) ${ }^{15}$, był

${ }^{12}$ Losy okiennicy pozostają nieznane. Jej wygląd uwieczniono w Katalogu zabytków sztuki w Polsce, t. 5: Województwo poznańskie, z. 12: Powiat leszczyński, Warszawa 1975, fig. 356. Kościół, zdewastowany u schyłku II wojny światowej przez żołnierzy Armii Czerwonej, którzy stacjonowali w jego wnętrzu, stał przez lata praktycznie niezabezpieczony. Do użytku nowo powstałej parafii katolickiej został oddany dopiero w latach 80. XX wieku.

13 Statut für das der evangelisch-lutherischen Kreuz-Kirche zu Lissa gehörige, durch Vereinigung mit dem St. Jeremias-Hospital erweiterte St. Georgen-Hospital, Lissa 1881, s. 2.

${ }^{14}$ Płyta nagrobna w lapidarium rzeźby nagrobnej w kościele św. Krzyża.

${ }^{15}$ W. Urban, Hentschel Samuel, w: Polski słownik biograficzny, t. 9, Wrocław 1960-1961, s. 426-427. Pełne dane biograficzne: Z. Herrmann, Die von Gott uns anbefohlene Himmels-Sorge..., Gedruckt zur Lissa durch Michael Bukken [po 5.02.1690], s. 19-24; egz. APP, sygn. 01.C.5/31. Uwaga: spośród wymienionych poniżej druków dotyczących Hentschela i członków jego rodziny oraz jego autorstwa, drukowanych 
znanym teologiem luterańskim, duchownym w leszczyńskim kościele Krzyża, od 1675 roku seniorem generalnym Kościoła. Przez kilka lat wykładał na uniwersytecie w Wittenberdze, następnie w latach 1662-1664 wypełniał obowiązki rektora gimnazjum w Oedenburgu na Węgrzech, a w 1664 roku osiadł w rodzinnym mieście. Pozostawił po sobie liczne dzieła z nurtu literatury budującej, a najbardziej znane z nich - Kleine Hauss-Postill... - przetłumaczono również na język polski. Od początku XVIII wieku na kartach ksiąg metrykalnych parafii luterańskiej w Lesznie występują ponadto noszący to nazwisko rzemieślnicy różnych specjalności, m.in. sukiennicy Johann Georg i Jeremias oraz robotnik najemny Gottfried $^{16}$.

Jeremias Hentschel ${ }^{17}$ urodził się w 1662 roku w Lesznie, w rodzinie mistrza garncarskiego Georga, który odnowił prawa miejskie 16 sierpnia $1661 \mathrm{roku}^{18}$. Z tego faktu wynika, że Hentschelowie mieszkali tu przed pożarem Leszna w 1656 roku, zapewne przybyli wraz z innymi uchodźcami w 1628 roku. Nic nie wiemy o matce i rodzeństwie Jeremiasa. Podstawową edukację zdobył $\mathrm{w}$ rodzinnym mieście. Przynajmniej w 1676 roku był uczniem miejskiej szkoły łacińskiej prowadzonej przez parafię luterańską. 30 maja tego roku wystąpił w sztuce Derer Regenten in Polen in einem deutschen Geschpräch-Spiele... wystawionej przez uczniów pod kierownictwem Johanna Beniamina Kretschmera. W spektaklu tym Hentschel odśpiewał ułożony osobiście tekst prologu sztuki ${ }^{19}$. Wraz z nim

w Lesznie, Szlichtyngowej i Wrocławiu w Bibliografii polskiej Karola Estreichera odnotowany jest tylko jeden: zob. przypis 37.

${ }^{16}$ APP, Akta stanu cywilnego parafii ewangelickiej Kreuzkirche Leszno.

${ }^{17}$ Krótki życiorys Hentschela przedstawia Ch.S. Thomas, Lesna erudita Lutherana, Posen 1938, s. 150-151 (nadbitka z "Deutsche Wissenschaftliche Zeitschrift für Polen", z. 35); T. Wotschke (Lissaer Studenten bis 1800, Posen 1930, s. 412, nadbitka z „Deutsche Wissenschaftliche Zeitschrift für Polen”, z. 19) błędnie podał, że Jeremias był synem Samuela Hentschela, seniora generalnego Kościoła ewangelicko-augsburskiego w Wielkopolsce. Sprostował go H. Harms w artykule Eine Schülerliste der lutherischen Lateinschule in Lissa i. W. von 1676 („Deutsche Wissenschaftliche Zeitschrift für Wartheland" 1943, z. 7-8, s. 216, przypis 35). Pokrewieństwo z seniorem Hentschelem wyklucza druk żałobny wydany po śmierci Samuela Hentschela. Zacharias Herrmann zadedykował go wdowie i wymienionym z imion dzieciom, wśród których nie znalazł się Jeremias. Podobnie w dołączonym do kazania życiorysie nie odnajdujemy naszego bohatera. Zob. Z. Herrmann, Die von Gott uns anbefohlene Himmels-Sorge..., Lissa [po 5.02.1690].

${ }^{18}$ H. Harms, Lissas Neubürger zwischen ersten und zweiten Stadtbrande (1661-1701), Posen 1942, s. 46.

${ }^{19}$ G. Smend, Evangelisches Schulwesens in Lissa. Ein Beitrag zur Entwicklung der Volkschule in der Provinz Posen, Lissa [s.a.] „Aus Lissas Vergangenheit”, z. 2, s. 69. 


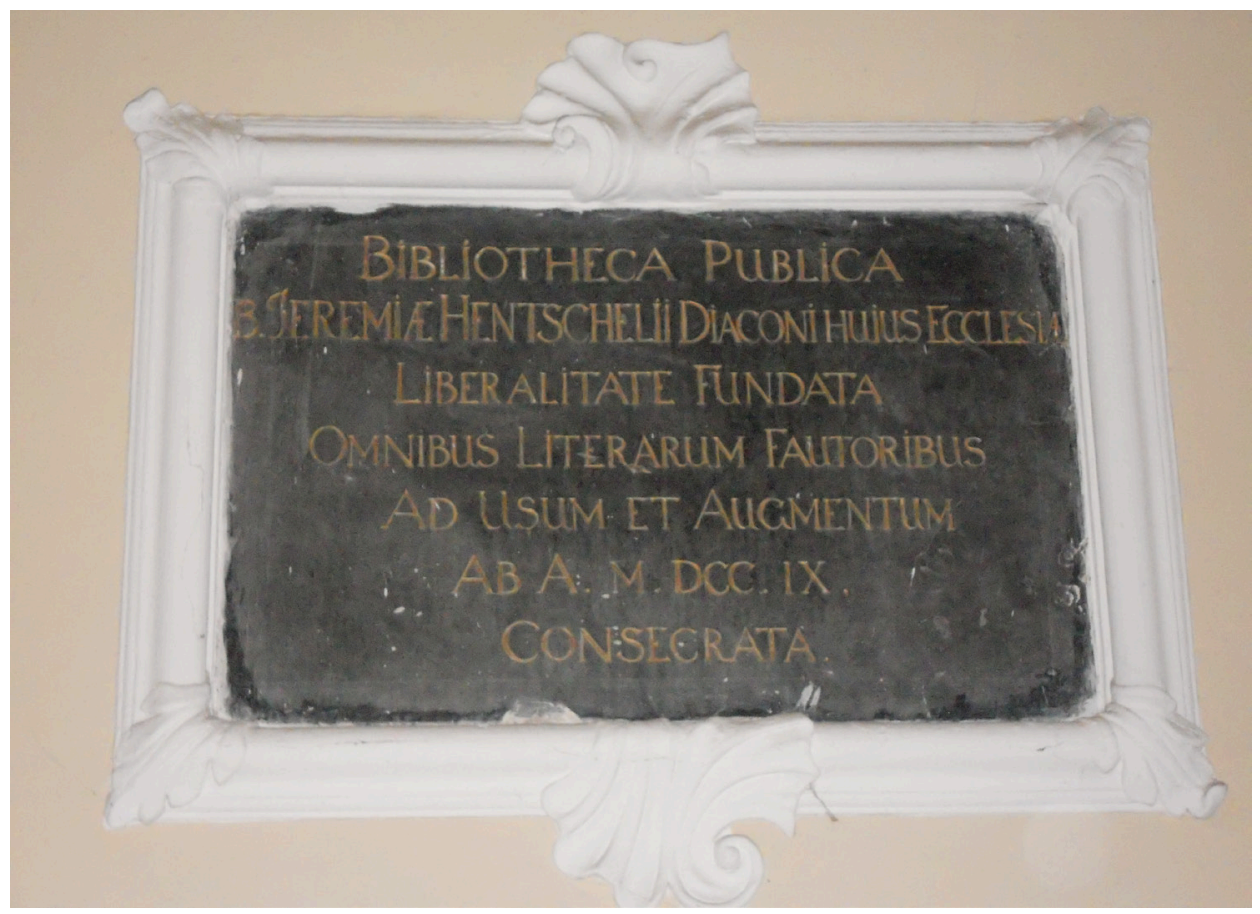

Il. 1. Tablica nad drzwiami biblioteki w kościele św. Krzyża w Lesznie Fot. Kamila Szymańska.

grało jeszcze 21 chłopców - nieliczni mieszkańcy Leszna i pobliskich miejscowości: Bojanowa, Rydzyny, Rawicza, położonych na Śląsku Czerniny, Głogowa, Kożuchowa, Wińska i Oławy oraz Beniamin Weisshaupt z Elbląga. Zdolności ucznia zostały dostrzeżone przez nauczycieli oraz nieokreślonych bliżej „Freunden und Brüder”, którzy udzielili mu wsparcia, by mógł kontynuować naukę w gimnazjum św. Elżbiety we Wrocławiu. Edukację tam skończył 11 maja 1682 roku. Następnie przez krótki czas studiował filologię, filozofię, teologię i historię Kościoła w Lipsku, by 3 maja 1683 roku zapisać się na uniwersytet w Jenie. Z okresu studiów w tym mieście zachowały się druki dysput, w których Hentschel uczestniczył. Poznajemy dzięki nim nazwiska nauczycieli lesznianina i jego kolegów - studentów. W 1684 roku ukazał się w Jenie zbiór tez bronionych pod kierunkiem profesora logiki i metafizyki Johanna Andreasa Schmidta (1652-1726), zatytułowany Brevis disquisitio de diversis disputatandi praessibus... (Jenae, Literis Wertherianis). Hentschel dysputował dwukrotnie, co potwierdzają broszury De termino theologiae naturalis, mysterio Trinitatis... oraz De fine formali theologiae naturalis... składające się na ten zbiór. W tym samym roku wydano dziewięć dysput, wspólnie pod zbiorczym 


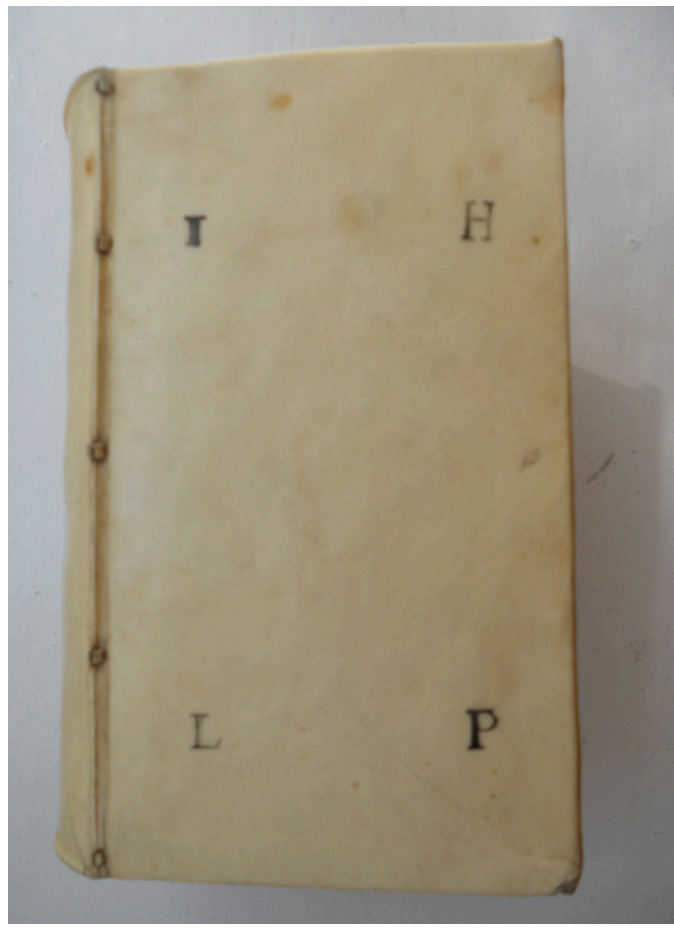

Il. 2. Okładka z superekslibrisem Jeremiasa Hentschela

Źródło: zbiory Muzeum Okręgowego w Lesznie. Fot. Kamila Szymańska.

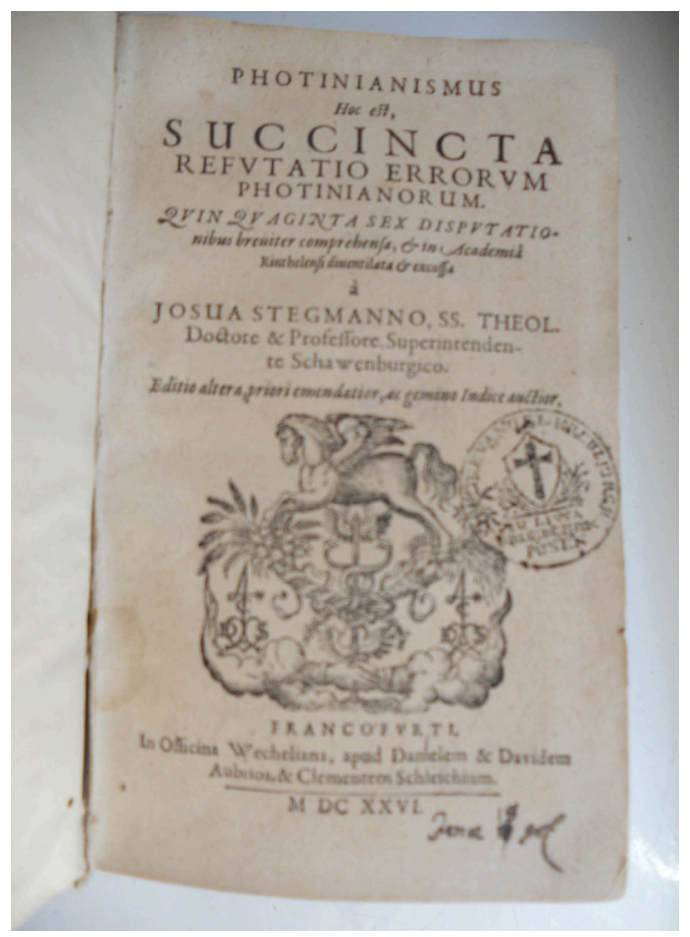

Il. 3. Karta tytułowa z notatką o miejscu i cenie zakupu

Źródło: zbiory Muzeum Okręgowego w Lesznie, sygn. S.82. Fot. Kamila Szymańska 
tytułem Disputatio iuridica de iur numellarum von Pranger-Recht... (Ienae, Typis Nisianis), firmowanych nazwiskiem promotora Johanna Volckmara Bechmanna (1624-1689). Wśród autorów znalazł się również Jeremias Hentschel. Dwa lata później ukazały się kolejne dysertacje jego autorstwa przygotowane pod opieką profesora Johanna Wilhelma Baiera (1647-1695), zatytułowane De Ecclesiae capite... i De peccatis originali et actualibus..., które znalazły się $\mathrm{w}$ zbiorze Collatio doctrinae pontificarum et protestantium disputationis XXVIII... (Ienae, Typis Gollnerianis). Edukacje na tej uczelni zwieńczyła praca egzaminacyjna Dissertatio philosophica de indifferentibus in genere morum... (Jenae, Typis Joh. Dav. Wertheri) przygotowana pod opieką Johanna Georga Müllera (1660-1721) i przedstawiona publicznie w czerwcu 1686 roku. Studia teologiczne na uniwersytecie w Jenie Hentschel ukończył 9 stycznia 1687 roku, co potwierdza drukowane zaświadczenie ${ }^{20}$.

18 lutego 1689 roku został ordynowany na stanowisko diakona do Rothenburga na Górnych Łużycach, w dobrach Johanna (Hansa) Heinricha von Hochberga ${ }^{21}$. Przebywał tam krótko, w 1690 roku wrócił do Leszna i zatrudnił się jako zastępca (substytut) seniora Hentschela, a w następnym roku został diakonem.

W tym czasie, będąc diakonem w Rothenburgu, wstąpił w związek małżeński z Marią Magdaleną Vogler. Ślub odbył się 3 maja 1689 roku w Lesznie, o czym dowiadujemy się z karty tytułowej wierszowanych gratulacji, ofiarowanych nowożeńcom przez leszczyńskiego primariusa Zachariasa Herrmanna ${ }^{22}$. Z tego związku urodził się syn Samuel, który zmarł 3 października 1691 roku w wieku dwóch lat. Diakon owdowiał

${ }^{20}$ Discessurus ex hac Academia vir-juvenis praestantissimus, Dn. Jeremias Hentschelus, Lesna-Polonus..., [Ienae], Literis Nisianis 1687 - egz. APP, sygn. 01.C.3/5. Za udostępnienie skanów druków znajdujących się w Archiwum Państwowym w Poznaniu, będących w trakcie katalogowania, dziękuję Panu drowi Michałowi Janeczkowi z Biblioteki Uczelnianej Państwowej Wyższej Szkoły Zawodowej im. J.A. Komeńskiego w Lesznie.

${ }^{21}$ G. Smend, Die Ordinationen in der lutherischen Kirche Grosspolens, "Aus Posens Kirchlicher Vergangenheit" R. IV, 1914, s. 4. Autor monografii Rothenburga, wydanej w 1844 roku, L.A.T. Holscher, również pomylił Jeremiasa z Samuelem, podając błędnie: „Samuel Hentschel, aus Polnisch Lissa, wo sein Vater Senior des geistlichen Ministerii war, gebürtig, erhielt 1688 den Ruf ins Rothenburger Diaconat, ging aber schon 1690 nach seiner Vaterstadt zurück, wo er an der Pest starb". Zob. http://de.wikisource.org/wiki/Kurze_Topographie_und_Geschichte_der_Kreis-Stadt_Rothenburg_in_der_Preu\%C3\%9F._Ober-Lausitz [dostęp: 15.11.2014].

${ }^{22}$ Das in dem angenehmen Mayen fröliche Hochzeit-Fest... Gedruckt zur Lissa durch Michael Bukken [1689] - egz. Biblioteki Uniwersyteckiej we Wrocławiu, sygn. 559392. 
13 maja 1706 roku - Maria Magdalena zmarła po dziewięciu miesiącach choroby na puchlinę wodną. Obydwa pogrzeby upamiętnili współpracownicy Hentschela, oddając pod prasę drukarską żałobne wiersze. Śmierć syna uczcili lesznianie z kręgu parafiii ${ }^{23}$ : Michael Lorentz Puschmann (1653-1734), Friedrich Held, Johann Beniamin Kretschmer (1653-1695) - niedawny nauczyciel Hentschela - oraz ukrywający się pod inicjałami: PAC, MJN i ABEH. O pozycji diakona w lokalnym środowisku i o jego związkach towarzyskich poza miejscem zamieszkania świadczą okolicznościowe druki, opublikowane po śmierci żony. Znamy cztery zbiorki wierszy przygotowane na tę okoliczność. Inicjatywa wydania dwu z nich wyszła ze środowiska wschowskiego. Podpisane zostały przez: „Das Fraustädtische Pristerliche Collegium” ${ }^{24}$ w osobach duchownych kościoła Żłóbka Chrystusa (Kripplein Christi): Joachima Klepperbeina (1663-1715), Samuela Friedricha Lauterbacha (1662-1728), pastora kościoła w Nowej Wschowie Christiana Bruschkego (zm. 1729) i pastora z Przyczyny Górnej Franza Teschnera (1674-1736) oraz "Collegium Scholasticum bey Kripplein Christi” ${ }^{25}$ reprezentowane przez rektora Johannesa Christiana Schindela, Christiana Blothnera, Davida Schultza, Pancratiusa Heina (zm. 1725) i Blasiusa Zeilera. Pozostałe utwory opublikowali lesznianie: nauczyciel w miejskiej szkole Emericus Friedwaldski (zm. 1730), urzędnik miejski Samuel Specht, LP (Lorentz Puschmann, 1653-1734) i wzmiankowany już PAC ${ }^{26}$ oraz MS (Martin Stiller?), który przypisał wiersz „des schmertzlich-betrübten Herren Wittwers alten treuen Schul-Freunde" ${ }^{27}$. Hentschel ożenił się powtórnie 15 lutego 1708 roku $^{28}$. Jego żoną została Regina Skade, córka wrocławskiego kupca Georga, wdowa po zamożnym leszczyńskim kupcu, asesorze rady i starszym parafii luterańskiej, Martinie Walterze (1658-1702). Z tej okazji ukazały się drukiem wierszowane gratulacje

${ }^{23}$ Als der... einig-erstes Kind und Söhnlein Namens Samuel... mit vielen Thränen bestatteten..., Gedruckt zur Lissa durch Michael Bukken [po 3.10.1691] - egz. APP, sygn. 01.C.3/7.

${ }^{24}$ Als der... Marien Magdalenen gebohrnen Volgerin schmertzlich betrübet worden..., Gedruckt zur Lissa durch Benjamin Friedrich Held [po 13.05.1706] - egz. APP, sygn. 01/C.3/44.

${ }^{25}$ Wohlmeinende Frost-Zeilen..., Gedruckt zur Lissa durch Benjamin Friedrich Held [po 13.05.1706] - egz. APP, sygn. 01.C.3/44.

${ }^{26}$ Trauer-Frost über dem höchst-schmertzlichen tödtlichen Hintritt..., Gedruckt zur Lissa durch Benjamin Friedrich Held [po 13.05.1706] - egz. APP, sygn. 01.C.3/43.

${ }^{27}$ Der ewige Sabath..., Gedruckt zur Lissa durch Benjamin Friedrich Held [po 13.05.1706] - egz. APP, sygn. 01.C.3/45.

${ }^{28}$ APP, Akta stanu cywilnego, Akta Małżeństw 1707-1781, s. 2. 
autorstwa duchownych, tym razem z pobliskiego Śmigla: Daniela Schellera (1675-1730), Samuela Günthera (1678-1737) i Beniamina Supkego, występujących na karcie tytułowej jako „Innen Beannte Schmiegler”29. Ze związku z Reginą przyszedł na świat w 1709 roku David Gottlob. Świadkami chrztu, który odbył się 27 maja tego roku, byli: senior Zacharias Herrmann i zamożni leszczyńscy mieszczanie - kupiec Abraham Keil i burmistrz Balthasar Adami ${ }^{30}$.

W kulturze słowa pisanego Hentschel uczestniczył czynnie, publikując zarówno wiersze, jak i obszerniejsze mowy żałobne. Kazaniami upamiętnił m.in. zmarłego seniora Samuela Hentschela ${ }^{31}$, żonę Zachariasa Herrmanna - Susannę Catharinę z Lincków ${ }^{32}$, Abrahama Goldammera zamożnego leszczyńskiego kupca, pełniącego funkcje starszego Kościoła i wójta ${ }^{33}$. Wraz z „,nachgesetzten Freunden” wydał wiersz upamiętniający żonę innego kupca, Martę Elisabeth Held ${ }^{34}$. Mowami i wierszami uczcił pamięć zasłużonych dla parafii reprezentantów leszczyńskiej luterańskiej elity. W tym gronie znalazł się kupiec, rajca i członek rady parafialnej Gottfried Held (1627-1692)35. W 1700 roku Hentschel pożegnał „Zu schuldigem Danck und rühmlichen Andencken der XII-jährigen treu-gepflogenen Freundschaft" Caspara Gräbera - starszego Kościoła i asesora ${ }^{36}$,

${ }^{29}$ Als der... Jeremias Hentschel... mit der... Regina gebohrnen Skadin... zur Lissa vergnügt sein proiesterliches Hochzeit-Festin..., In der Frey-Herrl. Stadt Schlichtingsheim, druckts Johann Christoph Wild [1708] - egz. Muzeum Okręgowego w Lesznie [dalej: MOL], sygn. S.53.

30 APP, Akta Urodzeń 1707-1722, s. 22.

${ }^{31}$ Die von Gott... bey volckreicher Leich-Bestattung des... Samuel Hentschels... in einer Abdanckungs-Rede..., Gedruckt zur Lissa durch Michael Bukken [po 9.02.1690] egz. APP, sygn. 01.C.5/32.

${ }^{32}$ Die heilige Gottes-Gelessenheit gläubiger Seelen... der... Susannae Catharinae Herrmannin..., gebohrnen Linckin... bey Ihren Grabe..., Gedruckt zur Lissa durch Michael Bukken [po 9.12.1691] - egz. APP, sygn. 01.C.2/11.

${ }^{33}$ Was besser als Gold bey... Leich-Bestattung des... Abraham Goldammers... an seiner Grab-Stäte..., Gedruckt zur Lissa durch Michael Bukken [po 15.04.1694] - egz. APP, sygn. 01.C.2/12.

${ }^{34}$ Gesamlete Liebes-Thränen, bey dem früh-zeitigen, höchst-schmertzlichen Absterben des... Martha Elisabeth Heldin, gebohrnen Weinbergin... aus herzlichen Mittleiden überreichet..., Gedruckt zur Lissa durch Michael Bukken [po 6.12.1691]: wersja elektroniczna: www.gbv.de/dms/vd17/14/5f/14:018280H_001,800,600git [dostęp: 27.02.2013].

35 Grab- und Ehren-Wahl..., Gedruckt zur Lissa durch Michael Bukken 1693 egz. APP, sygn. 01.C.5/27.

${ }^{36}$ Einen treuen Freund im Bilde des... Caspar Gräbers... am Tage seiner volckreichen Beerdigung..., Gedruckt zur Lissa durch Michael Bukken 1700 - egz. APP, sygn. 01.C.3/9. 
dwa lata później Georga Stolza - kupca i starszego Kościoła ${ }^{37}$. W 1709 roku upamiętnił, wydaną we Wrocławiu mową żałobną, Annę Susannę Rudolph z Helwigów, żonę leszczyńskiego kupca Michaela ${ }^{38}$. Zapewne znamy dziś jedynie fragment jego okolicznościowej twórczości. Wszystkie osoby, którym Hentschel poświęcił mowy, były członkami miejskiej elity, blisko związanymi z luterańską świątynią: duchownymi i członkami ich rodzin, zaś wymienieni świeccy - członkami rady parafialnej.

Jeremias Hentschel zmarł 14 października 1709 roku, w czasie epidemii dżumy, która dotknęła Wielkopolskę w latach 1707-1710. Wdowa wyszła ponownie za mąż 20 kwietnia 1710 roku za sukiennika Michaela Arleta $^{39}$, także wdowca. Zmarła w kwietniu 1722 roku i pochowana została „mit gantze Schule und einer Leichen Predigt" ${ }^{40}$. Wyróżnienie takim pochówkiem, w którym uczestniczyli wszyscy uczniowie szkoły luterańskiej, należy przypisać pamięci pierwszego męża zmarłej. Losy syna są nieznane; najprawdopodobniej niemowlę również było ofiarą zarazy, bo w przeciwnym razie diakon być może pozostawiłby dorobek swego życia jedynemu dziecku ${ }^{41}$.

Opatrzone superekslibrisem książki z biblioteki Jeremiasa Hentschela to dzieła nabyte podczas studiów w Jenie, gdzie przebywał w latach 1682-1687. Potwierdzają to daty roczne wytłoczone na licach okładek oraz tematyka oprawionych dzieł, wśród których dominują dysertacje studentów czołowych luterańskich uczelni, w tym liczne druki jeneńskie. Proweniencja Jeremiasa Hentschela to nie jedyny znak przynależności tych książek. Kilka tomów nosi ślady posiadania przez wcześniejszych właścicieli. Dzieło Felixa Bidembacha Promptuarii exequialis pars posterior (Francofurti, Apud Wolfgangium Richterum, Sumptibus Ioannis Berneri, 1610, ed. 2) ${ }^{42}$ nabył w 1617 roku nieznany MAS. Kilku użytkowników miało też dzieło Johanna Sleidana Commentatorium de statu religionis et Reipublicae Carolo V... (Francofurti, Apud

${ }^{37}$ Bey des Edlen... George Stoltzes... Leich-Bestattung..., Lissa, druckts Benjamin Friedrich Held [po 24.09.1702] - egz. Biblioteki Narodowej, sygn. XVII.4.10845adl. Zob. E. XVIII, 111.

${ }^{38}$ Ein dreifaches Weinstocks-Bild durch Versammlung..., Breslau, In der Baumannischen Erden Buchdruckerey, druckts Johann Jancker Factor [1709] - egz. Biblioteka Uniwersytecka we Wrocławiu, sygn. 420621.

39 APP, Akta Małżeństw 1707-1781, s. 10.

40 APP, Akta Zgonów 1722-1754, s. 2 - data dzienna jest nieczytelna z powodu dużych ubytków i zniszczenia papieru księgi.

${ }^{41}$ Księga zgonów parafii luterańskiej zachowała się od roku 1722.

${ }^{42}$ Egz. Biblioteki Kórnickiej PAN [dalej: BK PAN], sygn. 126539. 
Ioan. Th. Schwänwetterum, 1610) $)^{43}$. Swe nazwiska i daty roczne odnotowali kolejno: w 1627 roku Johannes Schleckenberger i Caspar Schellenbergh oraz pół wieku później Jo[hann]. Matt[haus]. Vogell. Innego właściciela przed Hentschelem miał tom Gottfrieda Reicha De Ecclesiae Romanae Apostasia in mysterio per acta... (Lipsiae, Typis J. Wittigau 1663) ${ }^{44}$ podpisany „H.D. Ronan Jan”.

Spośród ośrodków typograficznych reprezentowanych w zbiorze największy udział mają Wittenberga (30), Lipsk (27) i Jena (25), następnie Helmstädt (15) i Strasburg (12). Pozostałych 19 występuje w pojedynczych, maksymalnie pięciu egzemplarzach. Są to między innymi: Altdorf, Chur, Drezno, Erfurt, Frankfurt nad Menem, Genewa, Greifswald, Grimma, Kołobrzeg, Königsberg, Lejda, Marburg, Rostok, Rudolfstadt i Strasburg. Największy udział mają najsilniejsze centra ortodoksyjnego luteranizmu.

Większość prac została wydana w ciągu ośmiu lat: od 1675 do 1683 roku. Po cztery, pięć druków datowanych jest na lata 1663-1666. Najstarsze publikacje ukazały się w 1610 roku. Najliczniejsze są w tym zbiorze drobne, kilkustronicowe broszury $\mathrm{z}$ dysertacjami akademickimi, drukowane zawsze $\mathrm{w}$ formacie in quarto. Kilka prac to opasłe tomy, liczace ponad 1000 stron. Dzieła te zazwyczaj wydano w formacie in octavo lub in duodecimo.

Zasadniczy trzon księgozbioru tworzą dysertacje akademickie. Doskonała większość rozpraw odwołuje się do zagadnień teologii. Najpełniej reprezentowany jest uniwersytet w Lipsku z pracami pisanymi pod kierunkiem tamtejszych profesorów teologii i filozofii: Paula Antoniusa, Hieronymusa Kromayera, Johanna Friedricha Mayera, Petera Müllera, Johanna Oleariusa, Johanna Adama Scherzera i Jacoba Thomasiusa. Dalej wyróżniają się: Jena (Johann Wilhelm Baier, Johann Gerhard, Udalric Heinsius i Johann Musaeus) i Wittenberga (Balthasar Bebelius, Andreas Kunad, Johann Meissner i Johann Andreas Quenstadt). Pojedynczy promotorzy potwierdzają działalność wydziałów teologicznych w Helmstädt (Friedrich Ulrich Calixt), Greiswaldzie (Johann Friedrich König), Altdorfie (Heinrich Linck), Grimma i Strasburgu (Johann Schmidt). Najliczniejsze prace pisane były pod kierunkiem Calixta (12), Dannhauera (10), Meissnera (6) oraz Mayera, Oleariusa i Schmidta (po 4).

W zbiorze znajduje się jedna tylko Biblia, szczególna. Biblia Testamenti Veteris idiomate authentico expressa... to edycja Starego Testamentu

\footnotetext{
${ }^{43}$ Egz. BK PAN, sygn. 126619. Zob. E. XXVIII, 237.

${ }^{44}$ Egz. BK PAN, sygn. 236058.
} 
w języku hebrajskim w opracowaniu Davida Clodiusa, wydana we Frankfurcie nad Menem (Typis et Impensis Balthasaris Christop. Wustius) w 1677 roku $^{45}$. Ułatwieniem $w$ poruszaniu się po tekście jest łacińska żywa pagina i indeks. Można założyć, że Hentschel czytał Biblię $\mathrm{w}$ oryginale, bo $\mathrm{w}$ jego bibliotece znajdziemy też podręcznik do nauki języka hebrajskiego autorstwa Matthiasa Wasmutha zatytułowany Hebraismus facilitati et integrati... (Rostochi, Typis Johannis Kilii, Acad. Typogr. 1644, excudebat Joachimus Reumann, Acad. Typogr. 1666) ${ }^{46} \mathrm{w}$ trzech częściach. Oprócz Pisma Świętego diakon gromadził dzieła je komentujące, np. Commentarius in omnes epistolas... apostoli Pauli... cum textu graeco-latino... Friedricha Balduina (Francofurti, Typis et sumptibus Balthasari Christophori Wustius 1664) współwydany z Summae theologiae... Johanna Oleariusa ${ }^{47}$, nowe wydanie Schola prophetica articulorum symboli apostolici e prophetis excerptum... Daniela Cramera (Francofurti et Lipsiae, apud Fr. Ch. Coelium 1658) $)^{48}$ i Sebastiana Schmidta Commentarii super librum propheticorum Jeremiae... opera... w dwóch tomach (Francofurti ad Moenum, J.D. Zunner Haas 1685) ${ }^{49}$.

Jedyną pracą opisującą początki chrześcijaństwa jest dysertacja Jacoba Mullera Diatyposis Concilii Hierosolymitani... (Argentorati, typis haeredum J. Andreae 1648$)^{50}$, poświęcona synodowi jerozolimskiemu, który odbył się w 49 roku i był znaczącym wydarzeniem w procesie rozchodzenia się dróg judaizmu i konstytuującego się chrześcijaństwa. Muller oparł swe tezy na fragmencie Dziejów Apostolskich opisującym ustalone podczas obrad zasady nowego Kościoła, a skoncentrował się głównie na ogłoszonym podczas obrad odstąpieniu od żydowskiego zwyczaju obrzezania. Temu ostatniemu problemowi poświęcona była również dysertacja przygotowana przez Gottfrieda Weisse pod kierunkiem Paula Antoniusa De exercitationem historicam de circucisione gentilium... (Lipsiae, typis Chr. Güntheri 1682) ${ }^{51}$.

Z fundamentalnych prac dotyczących nauki Kościoła ewangelicko-augsburskiego należy wymienić Isagoge in libros Ecclesiarum Lutheranarum symbolicos... Johanna Benedicta Carpzova (Lipsiae, typis et impensis viduae et haeredum Joph. Wittgau 1675) ${ }^{52}$ i obszerna, trzytomową

\footnotetext{
45 Egz. BK PAN, sygn. 2594.

${ }^{46}$ Egz. BK PAN, sygn. 12640 adl.1-3.

47 Egz. BK PAN, sygn. 2592.

48 Egz. BK PAN, sygn. 2576.

49 Egz. BK PAN, sygn. 2374.

${ }^{50}$ Egz. BK PAN, sygn. 236065.

${ }^{51}$ Egz. BK PAN, sygn. 236038.

52 Egz. BK PAN, sygn. 2546 adl.1-2.
} 
Harmoniae evangelistarum... (Jenae, Typis et sumptibus Tobiae Steinmanni 1626$)^{53} \mathrm{w}$ opracowaniu czołowego ortodoksa luterańskiego Johanna Gerharda.

Trzy prace dotyczyły panowania cesarza Karola V Habsburga, którego rządy przypadły na czas rozprzestrzeniania się reformacji i lata życia Marcina Lutra ${ }^{54}$.

W zbiorze znajduje się kilka dzieł polemicznych w stosunku do innych wyznań protestanckich i katolickiego oraz - w kontekście historycznym - względem sekt wczesnochrześcijańskich. W obszernej pracy Summa controversiarum religionis... (Colbergae, Excudebat Joan. Kwicel) ${ }^{55}$ Johannesa Hoornbeeka, niderlandzkiego teologa, wydanej w Kołobrzegu w 1676 roku, znajdziemy opinie autora odnośnie do wszystkich wielkich religii i rozwijających się ruchów teofizycznych. W jednej z jedenastu ksiąg zebrany został materiał dotyczący katolicyzmu; tu Hoornbeek odnotował liczne fakty rozgrywające się na ziemiach polskich, ważne w dyskursie religijnym: zgoda sandomierska, colloquium charitativum czy katechizm rakowski. Krytyce teologów luterańskich poddawany był często arianizm. Zainteresowanie Hentschela tym wyznaniem, obecnym na ziemiach polskich, było chyba niemałe, bo kilka prac w jego księgozbiorze dotyczyło kwestii nauki arian. Posiadał na przykład drugie wydanie Photinianismus hoc est refutatio errorum photinianorum... (Francofurti, In Officina Wecheliana, apud Danielem et Davidem Ambrois et Clementem Schleichium 1626) ${ }^{56}$ Joshuy Stegmanna, zawierające 56 dysput, które razem ukazują wyczerpujący obraz tego wyznania (geneza, doktryna, obrządek, stosunek do urzędów i państwa, życie codzienne wyznawców). Podobną tematykę prezentuje Photinianae examen... (Erff[ordiae], Sumptibus Iohan. Brikneri Bibl. Escusum Typis Arnstadio-Schmidianis, 1656) $)^{57}$ Andreasa Keslera. Autor skupił się na filozoficznej ocenie pism socynian. To, że zagadnienia te bliskie były Hentschelowi, widzimy także w doborze dysertacji akademickich - wystarczy wymienić np.: Paula Höpnera Disputatio theologica de propitatione Christi... opposita pontificiorum, calvinistorum et photininiarum erroribus...

${ }^{53}$ Egz. BK PAN, sygn. 126378.

${ }^{54}$ J. Sleidan, Commentatorium de statu religionis et Reipublicae Carolo V, caesare libri XXVI..., Francofurti, apud Ioan. Th. Schwänwetterum 1610 - egz. BK PAN, sygn. 126619; A. Osiander, De morte Carolo V imperatori..., Lipsiae, J. Bielken 1682 egz. BK PAN, sygn. 236030; W. Steger, De interim Augustano..., Lipsiae, Typis Chr. Fleischeri 1683 - egz. BK PAN, sygn. 236032.

${ }^{55}$ Egz. MOL, sygn. S.62-3.

${ }^{56}$ Egz. MOL, sygn. S.82.

57 Egz. MOL, sygn. S.61-5. 
(Lipsiae, Literis Ch. Michaelis 1676) ${ }^{58}$, trzecie wydanie De origine et progressu arianismi... Christiana Webera (Wittebergae, Typis Chr. Schrödteri $1680)^{59}$ i trzecie wydanie rozprawy Alberta Grauera Libelles de unica veritate... (Jenae, Apud Joh. Ludocisum Neunhahn, typis Joh. Jacobi Bauhoferi $1665)^{60}$, polemizujące $z$ arianami i kalwinistami. W tej grupie odnotować trzeba dysertację Johannesa Gottlieba Thilla o Pawle z Samosaty (około 200-273), teologu reprezentującym nurt wczesnego chrześcijaństwa odmawiającego Chrystusowi natury boskiej, a tym samym negującym istnienie Trójcy Świętej ${ }^{61}$. Koncepcja ta legła o podstaw nauki takich ruchów, jak adopcjanie i paulicjanie, zaś podobieństwo doktryny zbliżało ich do arian. W tym kontekście wypowiada się autor tej ponad 60-stronicowej rozprawy, napisanej pod kierunkiem Johanna Wilhelma Baiera.

Kilka prac polemizowało z nauką Kościoła katolickiego. Najliczniejsze powstały w kręgu Johanna Friedricha Mayera (1650-1717): Chrysostomus Lutheranus orthodoxae veritatis adversus decreta Concilii Tridentinii assertor... (Grimmae, J. Bilken 1680) ${ }^{62}$ i Gewissens-Marter derer zum Papsthumb abgefallenen Lutheraner... (Lipsiae, J. Bielcke 1682) ${ }^{63}$. Reformom papieża Innocentego XI poświęcił ten sam autor Papstischer Cathechismus benebenst den Bedencken... Papst Innocenti XI... (Grimma, W. Chr. Kramer 1681) ${ }^{64}$ i wydane jako accedit Perinus Franciscus... Innocenti XI... excomunicatio dogmatum moralistarum... - rozprawę odnoszącą się do dekretów papieża z 1679 roku potępiających laksyzm. Hentschel posiadał też rozprawę firmowaną przez Johannesa Deutschmanna, zatytułowaną Collegium apostolico-lutheranum... contra calumnias in Deum... (Wittebergae, typis M. Henckelii 1676$)^{65}$, napisaną na podstawie polemiki węgierskiego jezuity Miklosa Kellio z Lutrem, oraz Gottfrieda Reicha De Ecclesiae Romanae apostasia in mysterio peracta... De invocatione sanctorum et cultu imaginum... (Lipsiae, Typis Johannis Wittgau 1663) ${ }^{66}$.

Nieodłącznym elementem pracy duszpasterskiej diakona było wygłaszanie kazań. W kontakcie z wiernymi uczęszczającymi na nabożeństwa

\footnotetext{
${ }^{58}$ Egz. BK PAN, sygn. 236017.

${ }^{59}$ Egz. BK PAN, sygn. 236091.

${ }^{60}$ Egz. BK PAN, sygn. 126371.

${ }^{61}$ Dissertationem historico-theologicam de Paulo Samosteno scinianorum patriarcha..., Jenae, typis J.J. Bauhoferi 1680 - egz. BK PAN, sygn. 236098.

${ }^{62}$ Egz. BK PAN, sygn. 236031.

${ }^{63}$ Egz. BK PAN, sygn. 236051.

${ }^{64}$ Egz. BK PAN, sygn. 236052.

65 Egz. BK PAN, sygn. 236057.

${ }^{66}$ Egz. BK PAN, sygn. 236058.
} 
nie zawsze wystarczało gruntowne wykształcenie teologiczne, nieodzowna była również znajomość realiów życia starotestamentowych Żydów, Chrystusa, Marcina Lutra. Pracy kaznodziejskiej miały służyć - oprócz wymienionych wyżej dzieł - praktyczne kompendia i zbiory gotowych kazań. Szczególnie pomocna była zapewne erudycyjna dwutomowa encyklopedia Johanna Feinlera zatytułowana Kirchen-Chronik oder Gottes Kirch-Garten... (Jenae, Druckts und Verlegts Georg Sengewald 1665) ${ }^{67}$, zawierająca wiadomości o faktach, postaciach, wydarzeniach, przedmiotach, faunie i florze opisanych w Starym i Nowym Testamencie. W korzystaniu z tej obszernej publikacji pomagał praktyczny indeks. Równie obszerny jest Catechismus Milch oder Erklärung dess Christlichen Catechismus Johanna Konrada Dannhauera ${ }^{68}$. Hentschel posiadał tomy 4-6, wydane w Strasburgu w wydawnictwie J.F. Spoora w latach 1669-1678. Zastosowanie znalazło na pewno 14 kazań ze zbioru Ornamentum Davidis aurem David und aller recht-gläubigen Guldenes Kleinod in königlicher Ehen-Schmuck (Rudolfstadt, bey C. Freyschmieden 1665) ${ }^{69}$ Daniela Fiedlera oraz Johanessa Friedricha van der Strass Memoria Thaumasiandri Lutheri renovata... (Argentoriati, typis Friderici Spoora 1683 - wyd. 2) ${ }^{70}$ napisane pod kierunkiem Dannhauera na podstawie zestawu dziesięciu kazań Matthiasa Hoe, zatytułowanego Sanctus Thaumasiander et triumphator Lutrus... Wyjątkowe w tym zbiorze są natomiast kazania żałobne autorstwa Johanna Benedicta Carpzova, upamiętniające zmarłego rektora lipskiego uniwersytetu Nicolausa Feinlera ${ }^{71}$ oraz Johanna Leonharda Schertzera ${ }^{72}$. Jakkolwiek gatunkowo utwory te należy łączyć raczej z literaturą okolicznościowa, zawarte $\mathrm{w}$ kazaniach treści teologiczne mogły inspirować Hentschela w jego twórczości pisarskiej.

Udział tekstów innych niż teologiczne jest niewielki, a i tak większość z nich silnie osadzona jest w nauczaniu Kościoła. Z zagadnień filozofii należy wymienić dysertacje: Gotthelta Ehrenreicha Bechera Dissertatio moralis de juris naturalis... (Lipsiae, literis viduae G. Niemanni 1682) ${ }^{73}$, Johanna Conrada Dürra Institutiones ethicae... (Altdorfi, Typ. et sumptibus

${ }^{67}$ Egz. BK PAN, sygn. 126399.

${ }^{68}$ Egz. BK PAN, sygn. 126370 adl.4-6.

${ }^{69}$ Egz. BK PAN, sygn. 236053.

${ }^{70}$ Egz. BK PAN, sygn. 236064.

${ }^{71}$ Ein feiner Student... Bey... Leichbestattung... Nicolai Feinler..., Ed. 2, Leipzig, durch Chr. Michaeln 1679 - egz. BK PAN, sygn. 236049.

${ }^{72}$ Gnothi se autor welches... bey... Leichbestattung... Johann-Leonhard Schertzes..., Leipzig, J. Wittgauens sel. Wittbe 1679 - egz. BK PAN, sygn. 236050.

${ }^{73}$ Egz. BK PAN, sygn. 236021. 
Henrici Meyeri, prostant Norimbergae, apud Wolfgang. M. Endterum et Joh. Andreae Endteri Filios 1680) ${ }^{74}$, De origine mentis humanae... (Altdorfi, Typis J.H. Schönnerstädt 1676) $)^{75}$ Johanna Conrada Feuerleina, Godfrieda Tummerella Ex philosophia practica dissertatione de conscientia... (Wittebergae, literis Z. Wilckii 1678) ${ }^{76}$ i Johanna Gottlieba Hardta Approbante... philosophorum senatu de vorticibus Cartesianis... (Lipsiae, literis J. Georgii 1682) ${ }^{77}$, będącą krytyczną oceną poglądów Kartezjusza.

Hentschel interesował się statusem nauk i uczonych w społeczeństwie miejskim. Dotyczą tego na przykład Johanna Matthaeusa Hopfnera De jure literaturm contra strepiferos... (Altdorfi, literis H. Meyeri 1680) ${ }^{78}$ i De plago literario accessiones... (Jenae, sumpt. Christoph. Enoch Buchta 1679) ${ }^{79}-$ dysertacja Johanna Michaela Reinela przygotowana pod opieką Jacoba Thomasiusa. $Z$ Thomasiusem wiąże się też rozprawa Jacoba Schmalca De foeminarum eruditionae... (Lipsiae, J.E. Hahn 1676) ${ }^{80}$ oparta na dziele uczonego, napisana pod kierunkiem Johanna Sauberbreia i przedstawiona publicznie w 1671 roku. Z perspektywy miejsca zamieszkania diakona praca ta ma wyjątkowy wymiar, bo wśród wyliczonych uczonych kobiet, głównie z kręgu kultury rzymskiej i włoskiego renesansu, oraz córek Melanchtona i Pirkheimera znajdujemy żyjącą w pierwszej połowie XVII wieku w Lesznie Annę Memoratę (ok. 1615 - ok. 1645) - córkę duchownego Jednoty braci czeskich, autorkę łacińskich wierszy, która skupiła wokół siebie grono adorujących jej talent poetów, także z kręgu miejscowej parafii luterańskiej.

$\mathrm{Z}$ zagadnień przyrodniczych $\mathrm{w}$ zbiorze znajdują się jedynie: Historia naturalis et civilis ad nostra usque tempora libri septem.... (Lipsiae, literis Johann-Erici Hahni 1671) ${ }^{81}$ autorstwa historyka i geografa Georga Horna oraz praca pochodzącego z Oławy Pantaleona Leutnera De alce... (Jenae, J.J. Bauhofer 1681 ${ }^{82} \mathrm{z}$ ilustracją na karcie tytułowej przedstawiającą jelenia. Jedyną publikacją o walorach historiograficznych jest Kaspara Sommera Onophagiam Silesiorum z 1677 roku $^{83}$, zawierająca reprezentację

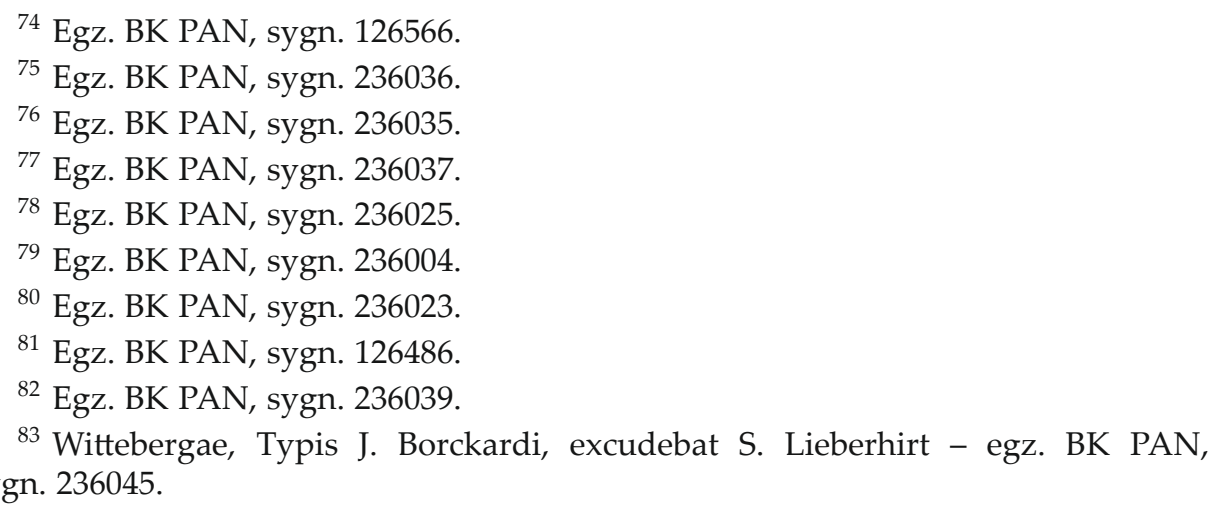


dzieł dotyczących Śląska, w tym również jego związków z Polską. Trzy rozprawy, które znajdowały się w bibliotece diakona, zdradzają zainteresowanie duchownego obyczajami, przesądami i kulturą ludową. Są to rozważania na temat Liczyrzepy ${ }^{84}$, zamiany noworodków przez istoty nadprzyrodzone ${ }^{85}$ i wróżenia $z$ sita ${ }^{86}$. Jedynym śladem literackiego gustu darczyńcy leszczyńskiej parafii jest genewskie wydanie epigramatów Marcusa Valeriusa Martialisa z 1623 roku.

Analiza księgozbioru ofiarowanego przez diakona nasuwa kilka spostrzeżeń. Z pewnością przekazane przez Hentschela tomy, opatrzone znakami proweniencyjnymi, to nie cała jego biblioteka. Trudno wyobrazić sobie, by luterański duchowny nie posiadał egzemplarza Biblii w języku ojczystym. W rodzinnym domu musiały się znajdować również katechizmy, postylle i inne przykłady literatury budującej - te pozostały na pewno do domowego użytku. Wraz z wymienionymi istniały zapewne w domowym księgozbiorze Hentschela podręczniki oraz, choćby nieliczne, teksty świeckie. Światło na lektury diakona rzucają także przypisy zamieszczane na marginesach mów żałobnych, gdzie obok najczęściej cytowanych ksiąg biblijnych występują pisma Swetoniusza, Plutarcha, Seneki, Augustyna i Grzegorza z Nazjanzu. Autor często powoływał się na Lutra oraz współczesnych mu i nieco wcześniejszych pisarzy i teologów (np. J. Lips, Monita ex exempla politica..., J. Masenius, Speculum imaginum veritatis occultae..., J.R. Camerarius, Horae natales, D. Saavedra, Idea prinicpe politice christiane..., Ch. Matthäus, Theatrum theoretico-practicum... czy Ch. Scriver, Seelen-Schatz...), nierzadko podając tylko ich nazwiska. Można przypuszczać, że dysponował tymi wydawnictwami. Przedmiotem daru były zatem te dzieła, które nabył podczas studiów, co udokumentował akronimem i datami rocznymi na okładkach, oraz - jak się wydaje - inne dzieła pozbawione znaków proweniencyjnych.

Bibliotekę Hentschela należy zaklasyfikować jako typowy zbiór religijny, uzupełniony o nieliczne utwory określające inne, nieznane skądinąd, zainteresowania Hentschela. Nieco urozmaicenia do monotonnego księgozbioru wnoszą prace o charakterze ludoznawczym i demonologicznym. Nie jest zaskakujące, że większość tekstów wyszła spod pióra czołowych reprezentantów ortodoksji luterańskiej. Z niektórymi z nich

${ }^{84}$ S.F. Trentzel, De spiritu... qui... nomine Rübezahl nuncpatur..., Wittebergae, literis J. Borcardi 1673 - egz. BK PAN, sygn. 236042.

${ }^{85}$ J.V. Merbitz, Biga disputationem physicarum..., [Dresden], J.Ch. Mithius, typis Chr. Baumanni 1678 - egz. BK PAN, sygn. 236040.

${ }^{86}$ J. Praetorius, De coscinomantia oder vom Giess-Laufte diatribe curiosa..., Curiae Variscorum, Ch.E. Buchta 1677 - egz. BK PAN, sygn. 236043. 
Hentschel miał okazję zetknąć się podczas studiów, poglądy i naukę innych poznał $\mathrm{z}$ ich dzieł oraz dysput akademickich pisanych pod ich kierunkiem. Większość owych rozpraw ma charakter odtwórczy, wtórny; niektóre doczekały się kilku wydań. Korzystając z nich, Hentschel czerpał wiedzę z drugiej ręki. Być może był to świadomy zamysł, wynikający z oszczędności - właściciel książek pochodził z niezamożnej rodziny, a zakup książek musiał być sporym wydatkiem dla ubogiego studenta.

\section{Bibliografia}

Als der... einig-erstes Kind und Söhnlein Namens Samuel... mit vielen Thränen bestatteten..., Gedruckt zur Lissa durch Michael Bukken 1691.

Als der... Jeremias Hentschel... mit der... Regina gebohrnen Skadin... zur Lissa vergnügt sein proiesterliches Hochzeit-Festin..., In der Frey-Herrl. Stadt Schlichtingsheim, druckts Johann Christoph Wild 1706.

Als der... Marien Magdalenen gebohrnen Volgerin schmertzlich betrübet worden..., Gedruckt zur Lissa durch Benjamin Friedrich Held 1706.

Bey des Edlen... George Stoltzes... Leich-Bestattung..., Lissa, druckts Benjamin Friedrich Held 1702.

Das in dem angenehmen Mayen fröliche Hochzeit-Fest..., Gedruckt zur Lissa durch Michael Bukken 1689.

Discessurus ex hac Academia vir-juvenis praestantissimus, Dn. Jeremias Hentschelus, Lesna-Polonus... [Ienae], Literis Nisianis 1687.

Der ewige Sabath..., Gedruckt zur Lissa durch Benjamin Friedrich Held 1706.

Die von Gott... bey volckreicher Leich-Bestattung des... Samuel Hentschels... in einer Abdanckungs-Rede..., Gedruckt zur Lissa durch Michael Bukken 1690.

Ein dreifaches Weinstocks-Bild durch Versammlung..., Breslau, In der Baumannischen Erden Buchdruckerey, druckts Johann Jancker Factor 1709.

Gesamlete Liebes-Thränen, bey dem früh-zeitigen, höchst-schmertzlichen Absterben des... Martha Elisabeth Heldin, gebohrnen Weinbergin... aus herzlichen Mittleiden überreichet..., Gedruckt zur Lissa durch Michael Bukken 1691.

Grab- und Ehren-Wahl..., Gedruckt zur Lissa durch Michael Bukken 1693.

Harms H., Lissas Neubürger zwischen ersten und zweiten Stadtbrande (1661-1701), „Deutsche Wissenschaftliche Zeitschrift im Wartheland" 1942, z. 5/6, s. 259-284.

Harms H., Eine Schülerliste der lutherischen Lateinschule in Lissa i. W. von 1676, „,Deutsche Wissenschaftliche Zeitschrift für Wartheland" 1943, z. 7-8, s. 209-226.

Die heilige Gottes-Gelessenheit gläubiger Seelen... der... Susannae Catharinae Herrmannin..., gebohrnen Linckin... bey Ihren Grabe..., Gedruckt zur Lissa durch Michael Bukken 1691.

Herrmann Z., Die von Gott uns anbefohlene Himmels-Sorge..., Gedruckt zur Lissa durch Michael Bukken 1690.

Katalog zabytków sztuki w Polsce, t. 5: Województwo poznańskie, z. 12: Powiat leszczyński, red. T. Ruszczyńska, A. Sławska Warszawa 1975. 
Kohte J., Geschichte der protestantischen Kirchenbaues in der Provinz Posen, "Zeitschrift der Historischen Gesellschaft für die Provinz Posen" 1897, t. 12, 1-32.

Kohte J., Die Kreuz-Kirche in Lissa, ein Denkmal des protestantischen Kirchenbaues, „Mitteilungen”, Historische Gesellschaft für Posen 1935, z. 3, s. 22-34.

Smend G., Evangelisches Schulwesens in Lissa. Ein Beitrag zur Entwicklung der Volkschule in der Provinz Posen, Lissa [s.a.].

Smend G., Die Kreuzkirche in Lissa. Ein Beitrag zu ihrer Baugeschichte, Lissa 1910.

Smend G., Die Ordinationen in der lutherischen Kirche Grosspolens, "Aus Posens Kirchlicher Vergangenheit" R. IV, 1914, s. 1-43.

Statut für das der evangelisch-lutherischen Kreuz-Kirche zu Lissa gehörige, durch Vereinigung mit dem St. Jeremias-Hospital erweiterte St. Georgen-Hospital, Lissa 1881.

Szymańska K., Dom ze stów... Wspólnota luterańska w Lesznie w XVII i XVIII wieku w świetle własnej spuścizny literackiej (rekonesans), w: Rzeczpospolita domów, t. 3: Domy Boże, red. K. Krawiec-Złotkowska, Słupsk 2012, s. 551-562.

Szymańska K., Losy księgozbiorów historycznych parafii ewangelickich w Lesznie, w: Dziedzictwo utracone - dziedzictwo odzyskane, red. A. Kamler, D. Pietrzkiewicz, Warszawa 2014, s. 201-221.

Szymańska K., Katalog starych druków Muzeum Okręgowego w Lesznie, Leszno 2001. Thomas Ch.S., Lesna erudita Lutherana, „Deutsche Wissenschaftliche Zeitschrift für Polen" 1938, z. 35, s. 143-161.

Trauer-Frost über dem höchst-schmertzlichen tödtlichen Hintritt..., Gedruckt zur Lissa durch Benjamin Friedrich Held 1706.

Einen treuen Freund im Bilde des... Caspar Gräbers... am Tage seiner volckreichen Beerdigung..., Gedruckt zur Lissa durch Michael Bukken 1700.

Urban W., Hentschel Samuel, w: Polski słownik biograficzny, t. 9, Wrocław 1960-1961, s. $426-427$.

Was besser als Gold bey... Leich-Bestattung des... Abraham Goldammers... an seiner Grab-Stäte..., Gedruckt zur Lissa durch Michael Bukken 1694.

Wohlmeinende Frost-Zeilen..., Gedruckt zur Lissa durch Benjamin Friedrich Held 1706.

Wotschke Th., Lissaer Studenten bis 1800, "Deutsche Wissenschaftliche Zeitschrift für Polen" 1930, z. 19, s. 123-141.

\section{KAMILA SZYMAŃSKA}

\section{Jeremias Hentschel Lesna Polonus (1662-1709) and his book collection. A section from the history of the library of the Lutheran parish in Leszno}

Aвstract. The article presents Jeremias Hentschel (1662-1709), the deacon of the Lutheran parish in Leszno, his own writings and the collection of books that he handed 
over to the parish library, also endowed by him. The deacon endowed the sum of 940 guilders for the construction of the building of the library as well as 144 works in 25 volumes that had been purchased by him between 1682-1687. The volumes have distinctive provenance marks: the acronym JHLP, standing for Jeremias Hentschel Lesna Polonus, embossed on parchment bindings of the books.

The collection includes numerous academic treatises and dissertations published in Orthodox Lutheran centers, notably in Jena and Wittenberg, as well as philosophical texts, materials on the history of the Church and polemics with other Christian denominations. Non-religious texts are scarce.

Key words: book collections, Protestantism, Leszno, provenances, the seventeenth and eighteenth centuries. 